\title{
FUSION VIA TRANSPSOAS LATERAL APPROACH: CONSIDERATIONS AND INITIAL RESULTS
}

\author{
ARTRODESE POR ACESSO LATERAL TRANSPSOAS: CONSIDERAÇÕES TÉCNICAS E RESULTADOS INICIAIS
}

\author{
ARTRODESIS POR ACCESO LATERAL TRANSPSOAS: CONSIDERACIONES TÉCNICAS Y \\ RESULTADOS INICIALES
}

Daniel de Abreu Oliveira ${ }^{1}$, Jonatas Sanchez Fernandez ${ }^{2}$, Roberto Sakamoto Falcon ${ }^{3}$, Cristiano Magalhäes Menezes ${ }^{3}$

\begin{abstract}
Objective: To present some technical considerations about interbody fusion by direct lateral retroperitoneal transpsoas approach and its initial results. Methods: Non-randomized prospective study of 14 patients undergoing interbody fusion via lateral approach, with evaluation of initial results and complications. Results: We collected and analyzed data from 14 patients with a total of 27 levels operated. The average operative time was 146 minutes and blood loss was on average less than $50 \mathrm{ml}$. Ten patients required supplemental percutaneous fixation with pedicle screws. VAS scores for the lumbar region and lower limbs and ODI had significant improvement in the postoperative period. There was an associated case of postoperative infection and thromboembolism that required reoperations. Conclusion: This technique has revolutionized the care of patients requiring fusion of T6-7 to L4-5. Following the five basic steps and using intraoperative monitoring, this technique is safe and reproducible with encouraging clinical results and low rate of serious complications.
\end{abstract}

Keywords: Surgical procedures, minimally invasive; Arthrodesis; Spine; Prospective studies; Treatment outcome.

\section{RESUMO}

Objetivo: Apresentar algumas considerações técnicas sobre a realização da artrodese intersomática por acesso lateral direto retroperitoneal transpsoas e seus resultados iniciais. Métodos: Estudo prospectivo não randomizado de 14 pacientes submetidos à artrodese intersomática por acesso lateral com avaliação dos resultados iniciais e complicações. Resultados: Foram coletados e analisados os dados de 14 pacientes com o total de 27 níveis operados. O tempo médio de cirurgia foi 146 minutos e o sangramento foi em média menor que $50 \mathrm{ml}$. Em 10 pacientes foi realizada a suplementação pedicular percutânea. Os escores da EVA lombar e para os membros inferiores, assim como o ODI tiveram melhora importante no pós-operatório. Houve um caso associado de infecção pós-operatória e tromboembolismo pulmonar que necessitou reintervenção cirúrgica. Conclusão: Esta técnica vem revolucionando o cuidado dos pacientes que necessitam fusão de T6-7 a L4-5. Seguindo os cinco passos básicos e utilizando a monitorização intraoperatória, a técnica é segura e reprodutível, com resultados clínicos animadores e pequena taxa de complicações graves.

Descritores: Procedimentos cirúrgicos minimamente invasivos; Artrodese; Coluna vertebral; Estudos prospectivos; Resultado de tratamento.

\section{RESUMEN}

Objetivo: Presentar algunas consideraciones técnicas sobre la realización de la artrodesis intersomática por acceso retroperitoneal lateral directo transpsoas y sus resultados iniciales. Métodos: Estudio prospectivo no aleatorizado de 14 pacientes sometidos a artrodesis intersomática por acceso lateral con evaluación de los primeros resultados clínicos y las complicaciones. Resultados: Se recogieron y analizaron datos de 14 pacientes con un total de 27 niveles operados. El tiempo quirúrgico promedio fue de 146 minutos y la pérdida de sangre fue en promedio de menos de $50 \mathrm{ml}$. En 10 pacientes se realizó la fijación pedicular percutánea suplementaria. Las puntuaciones de la EVA para la zona lumbar y las extremidades inferiores y el ODI tuvieron una mejoría significativa después de la cirugía. Hubo un caso postoperatorio asociado de infección y tromboembolismo que requirió reoperaciones. Conclusión: Esta técnica ha revolucionado el cuidado de los pacientes que requieren artrodesis de T6-7 a L4-5. Siguiendo los cinco pasos básicos y utilizando la técnica de monitorización intraoperatoria, esta técnica es segura y reproducible, con resultados clínicos alentadores y baja tasa de complicaciones graves.

Descriptores: Procedimientos quirúrgicos mínimamente invasivos; Artrodesis; Columna vertebral; Estudios prospectivos; Resultado del tratamiento.

\section{INTRODUCTION}

Pathologies of the spine are common causes of pain and functional incapacity in individuals of all age groups. ${ }^{1,2}$ Traditionally, many of these pathologies are treated surgically through arthrodesis of the affected segment. ${ }^{3}$ Interbody fusion has many theoretical advantages in relation to posterolateral fusion. It makes a larger area available for the fusion and, because the location of the graft is anterior to the axis of rotation, the system is expo- sed to greater loads of compression than of tension. The rate of pseudoarthrosis in posterolateral fusions is approximately 14$21 \%$. ${ }^{4,5}$ The fusion rate following interbody instrumentation varies depending on the technique, the implant, the type of graft, and the use of supplementary fixation. In general, this rate is higher than in isolated posterolateral fusions. ${ }^{6-10}$ Additionally, interbody construction is advantageous from the biomechanical perspective because without anterior support, the physiological loads of flexion can cause stress on the posterior pedicle screws. ${ }^{11}$ Anterior

1. NOT - Núcleo de Ortopedia eTraumatologia de Belo Horizonte, MG, Brazil.

2. Grupo Vertebral de Belo Horizonte, MG, Brazil.

3. Hospital Ortopédico/Lifecenter, Belo Horizonte, MG, Brazil.

Study conducted at the Hospital Ortopédico/ Lifecenter, Hospital Santa Rita, and Núcleo de Ortopedia eTraumatologia (NOT), Belo Horizonte, MG, Brazil.

Correspondence: Cristiano M. Menezes. NOT - Núcleo de Ortopedia eTraumatologia. Rua Aimorés, 2125. Lourdes, Belo Horizonte, MG, Brasil. cristianomenezes@me.com 
reconstruction of the spine provides immediate stability of the segment, increasing the resistance limit of the construction. The indications for interbody fusions are the same as for posterolateral fusion, and include degenerative disc disease, trauma, tumor, infection, deformity, and instability. ${ }^{12}$

The objective of interbody fusion is to obtain solid fusion, restoring the disc space and foraminal dimensions, as well as coronal and sagittal balance. Various approaches and techniques have been described to reach achieve this: posterior lumbar interbody fusion (PLIF), transforaminal lumbar interbody fusion (TLIF), and anterior lumbar interbody fusion (ALIF), each with its own peculiarities and risks. ${ }^{13-20}$ Recently, minimally invasive techniques have been the focus of much attention and interest aimed at minimizing the surgical trauma associated with the broad approaches used by other techniques. The minimally invasive TLIF technique is already a reality in our environment, yielding clinical results superior to those of conventional open surgery, with lower complication rates (chronic atrophy, paravertebral muscle dysfunction, and "fusion disease") and an earlier return to the activities of daily living. ${ }^{21}$

The extreme lateral interbody fusion (XLIF) approach (Nuvasive, San Diego, CA, USA) was popularized by Osgur et al..$^{22}$ It is a relatively new technique in which access to the disc is achieved via a lateral, retroperitoneal, and transpsoas approach. Blunt dissection of the psoas is performed using a series of dilators, the procedure being monitored in real time by electroneuromyography (ENMG) (Neurovision JJB Nuvasive, San Diego, CA, USA).23 This approach has significant advantages over anterior and posterior approaches, ${ }^{15-17}$ as it avoids the risks associated with the anterior approach, such as the mobilization of large vessels, lesions of the hypogastric sympathetic plexus, and lesions of the gastrointestinal and genitourinary systems. ${ }^{18-20}$ Furthermore, an approach surgeon is not required for the procedure. As compared to the posterior approach, we avoid injury and extensive muscle denervation, as well as retraction of the neural elements. ${ }^{15-17}$ In technical terms, the lateral approach has a gradual learning curve that is not as steep as for other minimally invasive techniques. ${ }^{23}$ This technique involves minimal damage to the soft tissues, minimal bleeding, reduced operating time, less postoperative pain, shorter hospitalization, and a rapid return to work. ${ }^{22}$

The objective of this study is to show the initial experiences of two surgeons using the interbody fusion technique via a lateral, retroperitoneal, transpsoas approach, focusing on the technical difficulties encountered, the initial results, complications, and safety.

\section{MATERIALS AND METHODS}

A prospective, non-randomized study of 14 patients who underwent minimally invasive lateral transpsoas approach interbody fusion was conducted. The same two spine surgeons, co-authors of this study, operated on all the patients. All patients who underwent right lateral retroperitoneal transpsoas interbody fusion during the period from September 2011 to January 2012 who presented intervertebral disc degeneration with stenosis and/or instability, adjacent level disease, pseudoarthrosis, mild spondylolisthesis, and/ or degenerative scoliosis were included in the study. One patient was excluded, after positioning on the radiotransparent table and marking of level L4-L5, when the approach was deemed impossible due to the height of the iliac crest, despite having conducted the preoperative planning. In this case, lateral approach surgery was aborted and direct transforaminal decompression with interbody fusion and minimally invasive pedicular instrumentation was performed with the patient in ventral decubitus. All patients signed the informed consent form.

A total of 27 levels were treated, ranging from one to four per patient, between L1 and L5. Supplementary instrumentation was performed in cases that presented instability confirmed by preoperative radiographs.

Visual analog scale (VAS) for the lumbar region and the lower limbs and Oswestry Disability Index (ODI) questionnaires were answered preoperatively, at 3 months, and at 12 months. In addition, the level of patient satisfaction with the surgery, and resulting complications, were collected.

The data were analyzed using the Student's t-test. $P$ values lower than 0.05 were considered statistically significant.

\section{SURGICAL TECHNIQUE}

The objective was not to describe the complete surgical technique in detail, but rather to focus on the most important aspects of the procedure.

The XLIF procedure must follow five critical steps: 1) positioning of the patient; 2) retroperitoneal approach; 3) transpsoas approach and exposure of the disc; 4) discectomy and preparation of the vertebral plates; and 5) placement of the interbody implant. ${ }^{23}$

For positioning of the patient, we must make sure that the table is radiotransparent and capable of bending in the middle section. The patient is placed in lateral decubitus with the great trochanter positioned at the break in the table and secured from behind with adhesive tape. (Figure 1) The table is then bent to increase the distance between the iliac crest and the ribs. A fluoroscope is used to obtain anteroposterior $(A P)$ and profile $(P)$ views, and we must change the position of the table, never the apparatus, to obtain a true orthogonal image.

For the approach we use an incision in the skin after marking the level with the fluoroscope, followed by two incisions in the fascia. When we need to access two levels, we make the incision in the skin between the level markers. (Figure 2) The posterolateral incision is used to access the retroperitoneal space with a gentle digital maneuver between the oblique abdominal muscles and the erector spinae muscle. After identifying the psoas and transverse process, the surgeon makes an incision in the fascia aligned with the axis of the fluoroscope to serve as his work portal. Then the initial dilator is introduced up to the psoas.

We must be familiar with the anatomy of the lumbar plexus in order to perform the introduction of the initiator. Studies have shown that the plexus is found in the posterior third of the disc in close proximity to the psoas, making a secure approach possible even in L4-L5. Additionally, the genitofemoral nerve runs along the anterior surface of the psoas from $L 2-L 3$, and preservation of this purely sensitive branch is of critical importance to prevent postoperative neuropathy. In order to perform dilation of the psoas safely and reproducibly, the transoperative use of the ENMG is critical to minimize the risks of injury to the lumbar plexus. After the introduction of the three sequential dilators, the retractor system (MaXcess, Nuvasive, San Diego, CA, USA) is put in place.

The discectomy is then performed using pituitary forceps and curettes. Execution of a contralateral annulotomy is indispensable. (Figure 3)

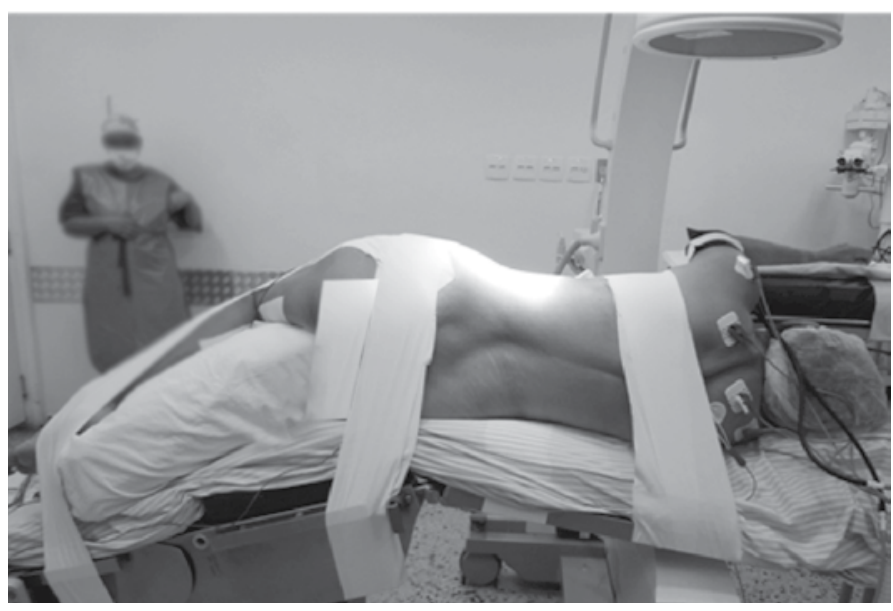

Figure 1. Positioning of the patient on the surgical table. 


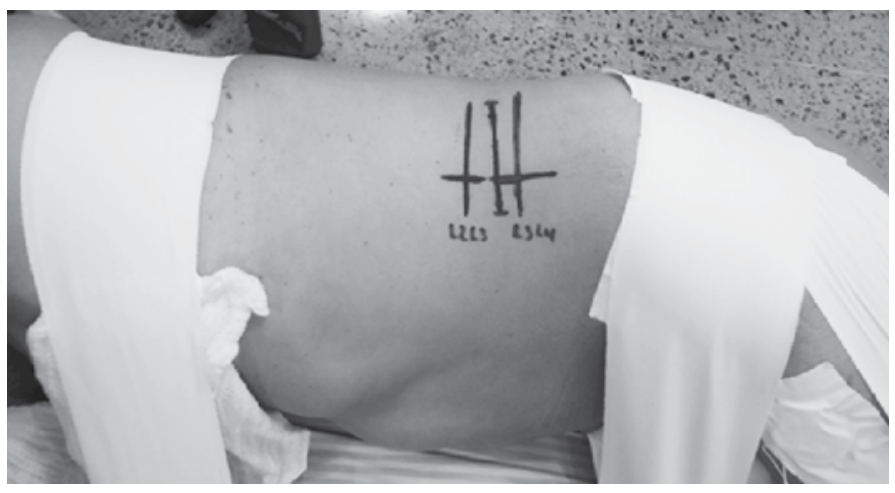

Figure 2. Marking of the levels and of the single skin incision between the two levels to be operated.

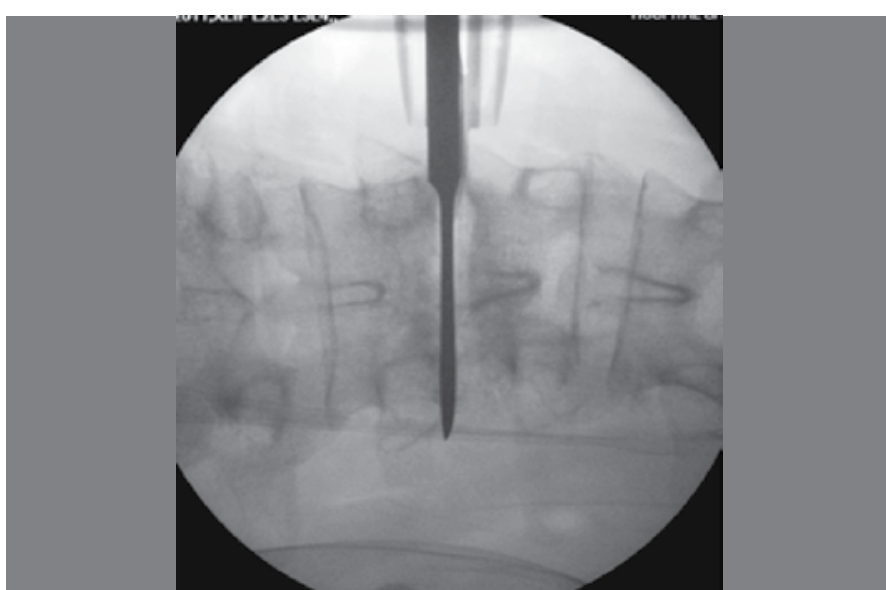

Figure 3. Detail of the contralateral annulotomy during the procedure.

The PEEK (poly-ether-ether-ketone) implant (CoRoent XL, Nuvasive, San Diego, CA, USA) is then positioned with the graft, having determined the appropriate dimensions through tests and using the fluoroscope.

If supplemental fixation is required a second surgical procedure is performed with the patient positioned in ventral decubitus, using the percutaneous pedicle screw fixation technique.

\section{RESULTS}

This study analyzed 14 patients with a total of 27 operated levels (Table 1). Of these patients, eight were female and six were male. Their ages ranged from 43 to 81 years (average of 64), with an average BMI of 27. The average surgical time was 146 minutes, and the average XLIF time was 59 minutes per level. Supplemental percutaneous pedicle screw fixation was performed in 10 patients. In 13 cases we used calcium triphosphate as the graft (Wright, Arlington, TN, USA) and in one case BMP-2 (Infuse, Medtronic, Memphis, TN, USA) was used. Average bleeding was less than $50 \mathrm{cc}$ and only one patient required a blood transfusion (three levels in two stages). Two patients required preventative postoperative ICU care due to comorbidities. The average overall hospitalization time was 3.3 days, or just 1.9 days if we count only the cases operated on in a single stage (total of 11 patients)

The lumbar and lower limb VAS and ODI are shown in Table 2. The improvement in these scores was statistically significant $(p<$ 0.001 ) in the evaluation at 3 months after surgery, and remained stable at 12 months. Table 3 shows the dimensions of the cages used in the surgeries.

Of the five patients who had jobs, four returned to work within an average of 3 weeks. Two patients presented fusion viewed in a computed tomography exam 18 months after surgery, and 13 patients stated that they were satisfied with the surgery (92\%). Minimally invasive posterior approach direct decompression was performed in one patient following XLIF, due to severe stenosis of the spinal canal.

In terms of complications, we had one case of postoperative infection associated with pulmonary thromboembolism in a patient who underwent surgery at two levels in combination with posterior pedicle screw instrumentation. Intervention was required in this patient to remove the cages and treat the infection.

One case presented psoas syndrome and four cases presented lateral paresthesia of the thigh, three of whom completely recovered after an average of 10.6 weeks and one of whom has not yet improved, though only six weeks have passed since surgery.

There was one case of subsidence of up to $10 \%$ of the body, which currently has stabilized with progressive signs of consolidation. There was one case of rhabdomyolysis with an expressive postoperative increase of CPK (three levels in a single stage with percutaneous pedicle screw fixation), which was appropriately monitored and treated with intravenous hydration. One patient still had residual discomfort of the thigh a year after surgery.

Figure 4 shows a case of degenerative scoliosis associated with spondylolisthesis and stenosis of the lumbar canal treated using this technique performed in two separate surgical procedures.

Table 1. Demographic data.

\begin{tabular}{|c|c|}
\hline Average age & 64 years \\
\hline$\%$ Male & 6 \\
\hline$\%$ Female & 8 \\
\hline Average BMI & 27 \\
\hline Average days of overall hospitalization & 3.3 \\
\hline $\begin{array}{l}\text { Average days of hospitalization with surgery } \\
\text { in } 1 \text { step (11 patients) }\end{array}$ & 1.9 \\
\hline \multicolumn{2}{|l|}{ Primary diagnosis } \\
\hline Spondylolisthesis & 5 \\
\hline DDD & 13 \\
\hline Scoliosis & 3 \\
\hline Adjacent level disease & 3 \\
\hline Pseudoarthrosis & 1 \\
\hline \multicolumn{2}{|l|}{ Distribution by levels } \\
\hline L1-L2 & $2(7 \%)$ \\
\hline L2-L3 & $8(29 \%)$ \\
\hline L3-L4 & $9(33 \%)$ \\
\hline L4-L5 & $8(29 \%)$ \\
\hline 1 level & $4(30 \%)$ \\
\hline 2 levels & $5(38 \%)$ \\
\hline 3 levels & $3(23 \%)$ \\
\hline 4 levels & $1(7 \%)$ \\
\hline Average follow-up time & 8 months \\
\hline Rate of minor complications & $15 \%$ \\
\hline Rate of major complications & $7.6 \%$ \\
\hline
\end{tabular}


Table 2. VAS and ODI scores. $(P<0.001)$.

\begin{tabular}{c|c|c|c}
\hline & Preop & $\mathbf{3 m}$ & $\mathbf{1 2 m}$ \\
\hline Lumbar VAS & 7.5 & $1.8(76 \%)$ & $2.33(69 \%)$ \\
\hline Lower limb VAS & 6.69 & $1.2(83 \%)$ & $0.6(91 \%)$ \\
\hline ODI & 46.2 & $13.6(70 \%)$ & $20(56 \%)$ \\
\hline
\end{tabular}

Table 3. Dimensions of the cages.

\begin{tabular}{c|c}
\hline $8 \times 18 \times 55$ & 5 \\
\hline $10 \times 18 \times 45$ & 4 \\
\hline $10 \times 18 \times 50$ & 7 \\
\hline $10 \times 18 \times 55$ & 4 \\
\hline $12 \times 18 \times 50$ & 2 \\
\hline $12 \times 18 \times 55$ & 5 \\
\hline
\end{tabular}

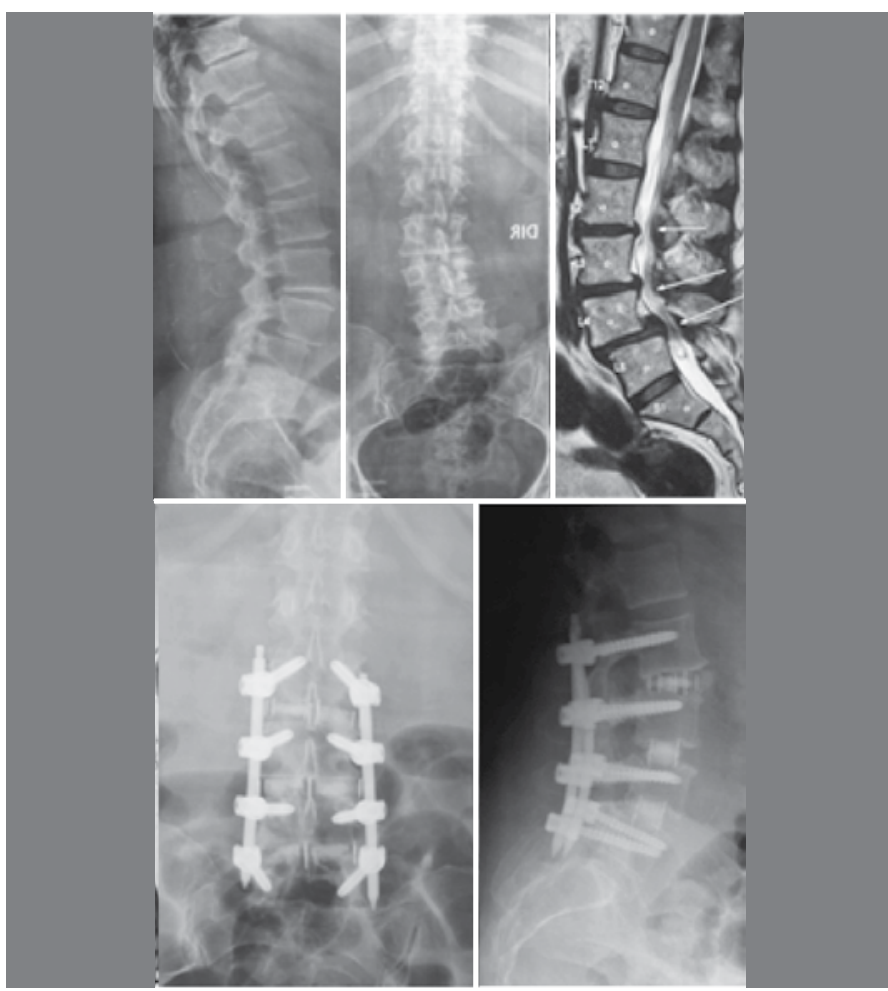

Figure 4. Note the significant improvement in coronal and sagittal balance, reduction of L4-L5 spondylolisthesis, restoration of height of the disc spaces, and increase of the neural foramens.

\section{DISCUSSION}

The lateral approach to the anterior spine is not, in fact, new, but it is historically defined in the literature as an alternative to the direct anterior approach. ${ }^{26-33}$ There have already been various anatomical descriptions of the retroperitoneum, the psoas, and the lumbar plexus. ${ }^{34-39}$

Rodgers et $\mathrm{al}^{40}$ reported initial results in 100 patients who underwent XLIF for multiple degenerative conditions in 2007. He described the procedure as safe and reproducible, with a low rate of complications (2\%), few days in hospital (average of 1.5 days), and good improvement of the VAS (68.7\%). In 2009, Rodgers et $\mathrm{al}^{41}$ reported the outcomes of 100 patients who underwent XLIF specifically for adjacent level disease. They spent an average of 1.13 days in the hospital, had a total complication rate of $9 \%$, transitory symptoms in the thigh at a rate of $1 \%$, and significant improvement in their pain scores (67.4\%). In 2010, Oliveira et al ${ }^{42}$ published a study of the fusion rate in 15 isolated XLIFs using BMP. The author reported a short operating time (67 minutes), little blood loss (average of $50 \mathrm{cc}$ ), short hospital stay (12 to 48 hours), and few minor complications (6.7\%). The patients improved in both pain and function scales. There were two repeated surgeries for direct posterior decompression.

In our study we encountered values similar to those in the literature for improvement of pain scores (76\%), for short surgical time (59 minutes per level of XLIF), and for blood loss (less than $50 \mathrm{cc}$ ). In terms of the number of days of hospitalization, we had a slightly higher average (3.3 days) because three procedures were performed in two steps (an average of four days between procedures) and we had one complication that required more time in the hospital for clinical treatment. When we analyze only the cases that were performed in a single step, we have an average hospitalization time of 1.9 days. We had a slightly higher complication rate than the literature: $15 \%$ of the cases with minor complications and $7.6 \%$ with major complications. This can probably be explained by the small case series in our study (14 patients) in which the occurrence of a single issue can impact the results significantly. We must also take into account the average follow-up time in our study of only eight months.

The XLIF technique is a modified retroperineal approach to the spine. It was first presented in 2001 by Pimenta ${ }^{43}$ who has performed more than 100 surgeries since 1998. However, there are limitations to this technique. The $12^{\text {th }}$ rib and the iliac crest can be impediments to the approach to the spine, a difficulty that we observed in one case in our study. Because of the transpsoas approach, we have a considerable number of patients who present transitory symptoms in the thigh. Moreover, as in other minimally invasive techniques, the duration of exposure to the fluoroscope is a limiting factor. $22,24,44$

The surgical outcomes of the procedure have shown that it is a safe and reproducible technique. ${ }^{45}$ Because it is a minimally invasive surgery, we observed rapid recovery and improvement in pain scores. XLIF is advantageous from a biomechanical perspective because it preserves the posterior and anterior osteoligamentary structures of the spine, restores disc height, and maintains stability because of the adequate width of the implant. This indirectly increases the foraminal space resulting in a reduction of radicular symptoms. Sagittal balance is improved when the implant is placed in a more anterior position, though it diminishes the potential for indirect decompression. Coronal balance is corrected due to the complete laterolateral covering of the apophyseal ring by the cage. Although it is early to evaluate the fusion rate in our study, all the patients who had completed 12 months since their surgeries presented consolidation and the others showed radiographic progress.

\section{CONCLUSION}

The XLIF technique has revolutionized the care of patients who require fusion from $T 6-7$ to $L 4-5$, offering another promising alternative for interbody fusion. The technique is safe, reproducible, and demonstrates encouraging clinical results with a low complication rate. Following the five basic steps and the use of transoperative neuromonitoring are critically important. However, we think that a longer patient follow-up time is necessary in order to obtain definitive long-term results.

All authors declare no potential conflict of interest concerning this article. 


\section{REFERENCES}

1. Du Bois M, Donceel P. Guiding low back claimants to work: a randomized controlled trial. Spine (Phila Pa 1976). 2012:37(17):1425-31.

2. Poitras $S$, Durand MJ, Côté AM, Tousignant M. Guidelines on low back pain disability: interprofessional comparison of use between general practitioners,occupational therapists, and physiotherapists. Spine (Phila Pa 1976). 2012;37(14):1252-9.

3. Eliyas JK, Karahalios D. Surgery for degenerative lumbar spine disease. Dis Mon. 2011;57(10):592-606

4. Parker LM, Murrell SE, Boden SD, Horton WC. The outcome of posterolateral fusion in highly selected patients with discogenic low back pain. Spine (Phila Pa 1976). 1996;21(16):1909-16.

5. Turner JA, Ersek M, Herron L, Haselkorn J, Kent D, Ciol MA, et al. Patient outcomes after lumbar spinal fusions. JAMA. 1992:268(7):907-11.

6. Ma GW. Posterior lumbar inter body fusion with specialized instruments. Clin Orthop Relat Res. 1985;(193):57-63.

7. Steffee AD, Sitkowski DJ. Posterior lumbar interbody fusion and plates. Clin Orthop Relat Res. 1988;227:99-102.

8. Calandruccio RA, Benton BF. Anterior lumbar fusion. Clin Orthop Relat Res. 1964;35:63-8.

9. Fujimaki $A$, Crock HV, Bedbrook GM. The results of 150 anterior lumbar inter body fusion operations performed by two surgeons in Australia. Clin Orthop Relat Res. 1982;(165):164-7.

10. Blumenthal SL, Baker J, Dossett A, Selby DK. The role of anterior lumbar fusion for internal disc disruption. Spine (Phila Pa 1976). 1988;13(5):566-9.

11. Cunningham BW, Sefter JC, Shono Y, McAfee PC. Static and cyclical biomechanical analysis of pedicle screw spinal constructs. Spine (Phila Pa 1976). 1993;18(12):1677-88

12. Kim DH. Lumbar fusion outcomes stratified by specific diagnostic indication. Spine J. 2009;9(6):520-1

13. Brantigan JW, Steffee AD. A carbon fiber implant to aid inter body lumbar fusion. Two-year clinical results in the first 26 patients. Spine (Phila Pa 1976). 1993:18(14):2106-7.

14. Gejo R, Matsui $H$, Kawaguchi $Y$, Ishihara $H$, Tsuji $H$. Serial changes in trunk muscle performance after posterior lumbar surgery. Spine (Phila Pa 1976). 1999;24(10):1023-8.

15. Kawaguchi $Y$, Yabuki S, Styf J, Olmarker K, Rydevik B, Matsui $H$, et al. Backmuscle injury after posterior lumbar spine surgery. Topographic evaluation of intramuscular pressure and blood flow in the porcine back muscle during surgery. Spine (Phila Pa 1976). 1996;21(22):2683-8

16. Rantanen J, Hurme M, Falck B, Alaranta $H$, Nykvist $F$, Lehto $M$, et al. The lumbar multifidus muscle five years after surgery for a lumbar intervertebral disc herniation. Spine (Phila Pa 1976). 1993;18(5):568-74.

17. SihvonenT, Herno A Paliärvi L, Airaksinen O Partanen J Tapaninaho A Local denervation atrophy of paraspinal muscles in postoperative failed back syndrome. Spine (Phila Pa 1976). 1993;18(5):575-81.

18. Sasso RC, Best NM, Mummaneni PV, Reilly TM, Hussain SM. Analysis of operative complications in a series of 471 anterior lumbar inter body fusion procedures. Spine (Phila $\mathrm{Pa}$ 1976). 2005;30(6):670-4.

19. Tiusanen H, Seitsalo S, Osterman K, Soini J. Anterior inter body lumbar fusion in severe low back pain. Clin Orthop Relat Res. 1996;(324):153-63.

20. Baker JK, Reardon PR, Reardon MJ, Heggeness MH. Vascular injury in anterior lumbar surgery. Spine (Phila Pa 1976). 1993;18(15):2227-30.

21. Menezes CM, Falcon RS, Ferreira Júnior MA, Alencar J. Avaliação clínica radiológica da artrodese lombar transforaminal aberta versus minimamente invasiva. Coluna/Columna. 2009;8(3):297-302

22. Ozgur BM, Aryan HE, Pimenta L, Taylor WR. Extreme lateral interbody fusion (XLIF): a novel surgical technique for anterior lumbar interbody fusion. Spine J. 2006;6(4):435-43.

23. Billinghurst J, Akbarnia BA. Extreme lateral interbody fusion - XLIF. Curr Orthop Pract. 2009:20:238-51.

24. Bergey DL, Villavicencio AT, Goldstein T, Regan JJ. Endoscopic lateral transpsoas approach to the lumbar spine. Spine (Phila Pa 1976). 2004;29(15):1681-8.
25. Dezawa A, Yamane T, Mikami H, Miki H. Retroperitoneal laparoscopic lateral approach to the lumbar spine: a new approach, technique, and clinical trial. J Spinal Disord. 2000;13(2):138-43.

26. Hovorka I, de Peretti F, Damon F, Arcamone H, Argenson C. Five years' experience of the retroperitoneal lumbar and thoracolumbar surgery. Eur Spine J. 2000:9(Suppl1):S30-4.

27. Lin RM, Huang KY, Lai KA. Mini-open anterior spine surgery for anteriorlumbar diseases. Eur Spine J. 2008;17(5):691-7.

28. Mayer HM. A new microsurgical technique for minimally invasive anteriorlumbar interbody fusion. Spine (Phila Pa 1976). 1997;22(6):691-9;

29. Mayer HM. The ALIF concept. Eur Spine J. 2000;9(Suppl 1):S35-43.

30. Mayer HM, Wiechert K. Microsurgical anterior approaches to the lumbar spinefor interbody fusion and total disc replacement. Neurosurgery. 2002;51(Suppl5):S159-65.

31. McAfee PC, Regan JJ, Geis WP, Fedder IL. Minimally invasive anterior retroperitoneal approach to the lumbar spine. Emphasis on the lateral BAK. Spine (Phila Pa 1976). 1998;23(13):1476-84.

32. Saraph V, Lerch C, Walochnik N, Bach CM, Krismer M, Wimmer C. Comparison of conventional versus minimally invasive extraperitoneal approach for anteriorlumbar interbody fusion. Eur Spine J. 2004;13(5):425-31.

33. Wolfla CE, Maiman DJ, Coufal FJ, Wallace JR. Retroperitoneal lateral lumbarinterbody fusion with titanium threaded fusion cages. J Neurosurg. 2002;96(Suppl 1):50-5.

34. Benglis DM, Vanni S, Levi AD. An anatomical study of the lumbosacral plexusas related to the minimally invasive transpsoas approach to the lumbar spine. J Neurosurg Spine. 2009;10(2):139-44.

35. Park DK, Lee MJ, Lin EL, Singh K, An HS, Phillips FM. The relationship of intrapsoas nerves during a transpsoas approach to the lumbar spine: anatomic study. J Spinal Disord Tech. 2010;23(4):223-8.

36. Paulino C, Patel A, Carrer A. Anatomical considerations for the extremelateral (XLIF) approach. Curr Orthop Pract. 2010;21:368-74.

37. Regev GJ, Chen L, Dhawan M, Lee YP, Garfin SR, Kim CW. Morphometric analysis of the ventral nerve roots and retroperitoneal vessels with respect to the minimally invasive lateral approach in normal and deformed spines. Spine (Phila Pa 1976). 2009;34(12):1330-5.

38. Regev GJ, Haloman S, Chen L, Dhawan M, Lee YP, Garfin SR, et al. Incidence and prevention of intervertebral cage overhang with minimally invasive lateral approach fusions. Spine (Phila Pa 1976). 2010;35(14):1406-11.

39. Uribe JS, Arredondo N, Dakwar E, Vale FL. Defining the safe working zones using the minimally invasive lateral retroperitoneal transpsoas approach: an anatomical study. J Neurosurg Spine. 2010;13(2):260-6.

40. Rodgers WB, Cox CS, Gerber EJ. Experience and early results with a minimally invasive technique for anterior column support through extreme lateral interbody fusion (XLIF). Musculoskelet Rev.2007;2:28-32.

41. Rodgers WB, Cox CS, Gerber EJ. Minimally invasive treatment (XLIF) of adjacent segment disease after prior lumbar fusions. J Minimally Invasive Spinal Technol 2009;3(4). Disponível em http://ispub.com//JMIST/3/4/7005.

42. Oliveira L, Marchi L, Coutinho E, Abdala N Pimenta L. The use of rh-BMP2 in standalone extreme lateral interbody fusion (XLIF): clinical and radiological results after 24 months follow-up. World Spinal Column J. 2010;1: 19-25.

43. Pimenta $L$. Lateral endoscopic transpsoas retroperitoneal approach for lumbar spine surgery. In: VIII Encontro da Sociedade Brasileira de Coluna, Belo Horizonte, 2001.

44. Nakamura H, Ishikawa T, Konishi S, Seki M, Yamano Y. Psoas strapping technique: a new technique for laparoscopic anterior lumbar interbody fusion. J Am Coll Surg. 2000;191(6):686-8

45. Amaral R, Marchi L, Oliveira L, Coutinho T, Castro C, Castro E, et al. Opção minimamente invasiva lateral para artrodese intersomática tóraco-lombar. Coluna/Columna. 2011;10(3):239-43. 